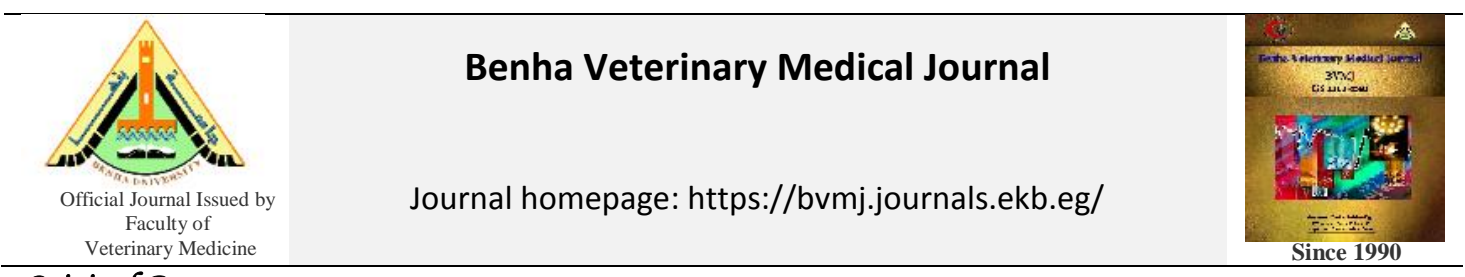

Original Paper

\title{
Effect of Flavomycin and Synbiotic on experimentally-infected common carp with Pseudomonas aeruginosa
}

\author{
Hamada El Azzy ${ }^{1}$, El Sayed, M. ${ }^{1}$, Hend megahed ${ }^{2}$, Nahad Kmoura ${ }^{3}$ and Eman I. Soror ${ }^{4}$ \\ ${ }^{1}$ Bacteriology, ${ }^{2}$ Biochemistry and ${ }^{3}$ Clinical Pathology Departments, Animal Health Research Institute (Zagazig branches) \\ ${ }^{4}$ Aquatic Animals Diseases and Management Department, Faculty of Veterinary Medicine, Benha University
}

\begin{tabular}{|c|c|}
\hline ARTICLE INFO & ABSTRACT \\
\hline $\begin{array}{l}\text { Keywords } \\
\text { Common carb } \\
\text { Flavomycin } \\
\text { Hematobiochemical } \\
\text { Pseudomonas aeruginosa }\end{array}$ & $\begin{array}{l}\text { This study investigated the antibacterial effect of flavomycin and synbiotic against } \\
\text { Pseudomonas aeruginosa (P. aeruginosa) beside the weight gain and haemato-biochemical } \\
\text { changes in common carp. Apparently healthy } 150 \text { common carp weighing } 110 \pm 10 \mathrm{~g} \text { were } \\
\text { divided into six equal groups. The } 1^{\text {st }} \text { group received basal diet without any additives (control } \\
\text { group). The } 2^{\text {nd }} \text { group received basal diet with } 8 \mathrm{mg} / \mathrm{kg} \text { diet flavomycin for } 30 \text { days. The } 3^{\text {rd }} \\
\text { group received basal diet with } 3 \mathrm{mg} / \mathrm{kg} \text { diet synbiotic for } 30 \text { days. Fish in } 4^{\text {th }}, 5^{\text {th }} \text { and } 6^{\text {th }} \\
\text { groups were experimentally infected with } P \text {. aeruginosa. The } 4^{\text {th }} \text { group was left untreated. } \\
\text { The } 5^{\text {th }} \text { and } 6^{\text {th }} \text { groups were treated with } 8 \mathrm{mg} / \mathrm{kg} \text { diet flavomycin or } 3 \mathrm{mg} / \mathrm{kg} \text { diet symbiotic, } \\
\text { respectively for } 5 \text { days. Swabs were collected to isolate } P \text {. aeruginosa. Blood samples were } \\
\text { collected for haemato-biochemical analysis. Healthy fish received flavomycin or synbiotic } \\
\text { revealed significant increase in body weight gain, RBCs, Hb, PCV with non-significant } \\
\text { increase in total protein, albumin, globulin, A/G ratio, AST, ALT, urea, creatinine. Infected } \\
\text { fish with } P \text {. aeruginosa showed tail and fin rot, hemorrhagic ulcerative skin, superficial } \\
\text { ulcers beside mortality rate up to } 32 \% \text { with significant decrease in body weight, RBCs, HB, } \\
\text { PCV } \% \text {, total protein, albumin, globulin and significant elevation in AST, ALT, ALP, urea and } \\
\text { creatinine. Infected fish treated with flavomycin or synbiotic improved the clinical signs, } \\
\text { reduced mortality rate to } 8 \% \text { and } 12 \% \text {, respectively, and decreased rate of infection. In } \\
\text { conclusion, flavomycin or synbiotic have an effective antibacterial effect against } P \text {. } \\
\text { aeruginosa. }\end{array}$ \\
\hline
\end{tabular}

\section{INTRODUCTION}

Fish culture is an important industry where the production of fish is increasing worldwide. Supplementation of natural components in fish ration improved performance of fish without any harmful effect (El-Ghamry et al., 2002).

Several Bacterial infections are responsible for losses of fish industry through increasing mortality and reducing weight gain. Many bacteria are considered to be saprophytic in nature able to cause diseases when fishes are immune- compromised (Khalil et al., 2001). Pseudomonas spp. is considered a widely spread in natural sources of water and associated with septicemia in fish farms (Roberts, 2001).

Fish is susceptible to $P$. aeruginosa with moderate to high losses (Somsiri and Soontornvit, 2002). Main signs appear with Pseudomonas infection are hemorrhage in the skin at mouth region, opercula and ventral side of body (Wakabayashi and Egusa, 1972).

Many antibiotics are used to promote growth and health in common carp by improving performance (Parker and Armstrong, 1987), preventing the spread of diseases and increasing body gain (Reilly and Kaferstein, 1997). Flavomycin is a phosphoglycolipid antibiotic that acts by inhibiting bacterial growth (Van Heijenoort, 2001). It inhibits two groups of bacteria; one is from the group of high activity ammonia production and also gram-negative bacteria (Edwards, et al., 2005). It is used as growth promoters for farmed fish in China (Li et al., 2008).

Synbiotic is defined as mixture of probiotics and prebiotics that positively affects host by improving the implantation and survival of live microbial feed supplements in the digestive system (Hassanpour et al., 2013). Synbiotics have been provided different health benefits as resistance to gut bacterial infection and antibacterial effect and immunomodulatory activities in broilers (Ghasemi et al., 2014).

The aim of this study was to investigate the influence of ration supplemented with flavomycin and synbiotic on controlling $P$. aeruginosa beside its effect on growth performance and certain hematobiochemical parameters in common carp.

\section{MATERIAL AND METHODS}

\subsection{Fish and experimental design}

A total of 150 growing apparently healthy common carp weighing $110 \pm 10 \mathrm{~g}$ maintained in well-aerated glass aquaria (about 100 liters capacity) filled with dechlorinated tap water of about $\mathrm{pH} 7.2$ and $25^{\circ} \mathrm{C}$ temperature. Cleaning

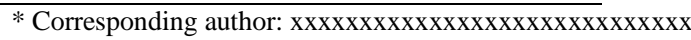


of water was carried out weekly. A balanced ration, $4 \%$ of fish body weight was given. Fish was acclimatized to the laboratory conditions for one week before starting the experiment.

Fish were randomly divided into six equal groups $(n=25)$. The first group received basal diet without any additives (control group). The second group received basal diet with $8 \mathrm{mg} / \mathrm{kg}$ diet flavomycin for 30 successive days (Fairchild et al., 2001). The $3^{\text {rd }}$ group received basal diet with $3 \mathrm{mg} / \mathrm{kg}$ diet synbiotic for 30 successive days. Fish in the $4^{\text {th }}, 5^{\text {th }}$ and $6^{\text {th }}$ groups were experimentally infected with $P$. aeruginosa (injected intra peritoneal with $0.2 \mathrm{ml}$ of trypticase soya broth containing $3 \times 10^{7} \mathrm{cfu} / \mathrm{ml} \quad P$. aeruginosa (Eissa et al., 2010). The $4^{\text {th }}$ group infected fish were left untreated. The $5^{\text {th }}$ group fish were infected and treated with $8 \mathrm{mg} / \mathrm{kg}$ diet flavomycin for 5 successive days. The $6^{\text {th }}$ group fish were infected and treated with $3 \mathrm{mg} / \mathrm{kg}$ diet synbiotic for 5 successive days. Treatment started post clinical signs appearance.

\subsection{Materials}

2.2.1.Drugs

2.2.1.1. Flavomycin (Pharmastim 4\%®)

It is growth promoter produced by Biovet Peshtera (Peshtera, Bulgaria)

2.2.1.2. Synbiotic (PoultryStar sol.®)

It is produced by Biomin -Austria. It was distributed by Dakahlia Poultry Comp. Egypt. It is present in the form of $100 \mathrm{gm}$ sachets contain Enterococcus Faecium, Bifidobacerium Animalis, Pediococcus Acidilactici and Lactobacillus Salivarius as probiotics and fructooligosaccharides as prebiotics.

\subsubsection{Bacteria:}

Pathogenic strain of Pseudomonas aeruginosa obtained from Bacteriology Department, Fac. of Vet. Medicine, Zagazig University, was used for experimental infection of fish.

\subsubsection{Diet:}

The fish were fed on basal diet with the following composition:

\begin{tabular}{lc} 
composition: & $\%$ in diet \\
\hline Ingredients & $40 \%$ \\
Soybean meal & $8 \%$ \\
Fish meal & $30 \%$ \\
Ground corn & $15 \%$ \\
Wheat flour & $3 \%$ \\
Vegetable oil & $1 . \%$ \\
Cod liver oil & $1.50 \%$ \\
Dicalcium phosphate & $1 \%$ \\
Vitamins/minerals premix & \\
\hline
\end{tabular}

\subsection{Swabs collection, culture and identification}

Swabs from skin and gills were collected on the first day post treatment period from all treated and untreated common carp. The swabs were streaked on nutrient agar plates and the plates were incubated at $37^{\circ} \mathrm{C}$ for 24 hours as described by Cheesborough (1985). The characteristic suspected single colonies were subjected to Gram's staining and then sub-cultured in MacConkey agar and blood agar. $P$. aeruginosa was identified by biochemical test (sugar fermentation test) and biochemical tests were performed following the methods described by MacFadden et al. (2000). Motility test of the isolated $P$. aeruginosa was performed following the method described by Cheesborough (1984).

\subsection{Body performance}

The fish of each group were weighed at start of the experiment and at last day post supplementation to obtain the body weight gain as indicator for body performance.

\subsection{Blood and serum samples}

Two blood sample were collected from caudal vein of fish in at the last day post supplementation. The $1^{\text {st }}$ sample was collected in tube contain EDTA as anticoagulant for erythrogram estimation according to Jain (1986), the $2^{\text {nd }}$ sample was collected to obtain serum for estimation of total protein (Doumas et al. 1981), albumin (Drupt, 1974) and globulin was calculated mathematically. Serum was also used for biochemical determination of AST and ALT (Reitman and Frankel 1957), urea (Fawcet and Scott, 1960) and creatinine (Husdan and Rapoport, 1968).

\subsection{Statistical analysis:}

The obtained data were statistically analyzed by using oneway analysis of variance (ANOVA) according to Petrie and Watson (1999).

\section{RESULTS}

\subsection{Clinical signs}

Common carp infected with $P$. aeruginosa showed clinical signs as hemorrhages on body surface, ulcerative skin, tail and fin rot, superficial ulcers with $32 \%$ mortality. The treatment with flavomycin and synbiotic reduced the mortality rate to $8 \%$ and $12 \%$, respectively (Table 1 ).

\begin{tabular}{|c|c|c|c|c|}
\hline \multirow[t]{2}{*}{ Groups } & \multirow{2}{*}{$\begin{array}{c}\text { Total } \\
\text { no }\end{array}$} & \multicolumn{2}{|c|}{ Mortality rate } & \multirow{2}{*}{$\begin{array}{l}\text { Re-isolation of } \\
P \text {. aeruginosa }\end{array}$} \\
\hline & & no & $\%$ & \\
\hline Control group & 25 & 0 & 0 & 0 \\
\hline Flavomycin & 25 & 0 & 0 & 0 \\
\hline Synbiotic & 25 & 0 & 0 & 0 \\
\hline Infected & 25 & 8 & 32 & $17 / 17$ \\
\hline Infected with Flavomycin & 25 & 2 & 8 & $5 / 23$ \\
\hline Infected with Synbiotic & 25 & 3 & 12 & $6 / 22$ \\
\hline
\end{tabular}

3.2. Biochemical characteristics of $P$. aeruginosa

$P$. aeruginosa was identified as Gam-negative short rod bacteria with yellow green colonies. The biochemical tests showed a characteristic pattern with positive oxidase, methyl red, maltose, and catalase with negative indole production.

\subsection{Body index}

Healthy common carp received flavomycin and synbiotic each alone revealed significant $(p) \quad 0.05)$ elevation in body weight gain. $P$. aeruginosa infection in common carp induced significant decrease in body weight gain. Infected fish treated with flavomycin and synbiotic showed significant increase in body weight gain compared to infected group (Table 2).

\subsection{Hematological changes}

Infected common carp with P. aeruginosa showed significant reduction ( $p \quad 0.05)$ in $\mathrm{RBCs}, \mathrm{Hb}$ and $\mathrm{PCV}$ compared to control. Fish received flavomycin or synbiotic showed significant elevation in RBCs, $\mathrm{Hb}$ and PCV. Common carp infected with $P$. aeruginosa and received flavomycin or synbiotic showed significant increase in 
RBCs. $\mathrm{Hb}$ and PCV compared to fish infected with $p$. aeruginosa (Table 3 ).

Table 2 Effect of $P$. aeruginosa and treatment on body weight gains of common carp $(\mathrm{n}=5)$.

\begin{tabular}{llll}
\hline Groups & Initial body weight & Final body weight & Weight gain \\
\hline Control group & $116.04 \pm 0.43^{\mathrm{a}}$ & $140.86 \pm 1.73^{\mathrm{b}}$ & $24.82 \pm 1.98^{\mathrm{b}}$ \\
Flavomycin & $115.21 \pm 0.37^{\mathrm{a}}$ & $146.14 \pm 1.98^{\mathrm{a}}$ & $30.93 \pm 1.02^{\mathrm{a}}$ \\
Synbiotic & $116.16 \pm 0.28^{\mathrm{a}}$ & $145.48 \pm 1.88^{\mathrm{a}}$ & $29.32 \pm 1.18^{\mathrm{a}}$ \\
Infected & $116.19 \pm 0.26^{\mathrm{a}}$ & $127.21 \pm 1.87^{\mathrm{d}}$ & $11.82 \pm 1.96^{\mathrm{c}}$ \\
Infected with Flavomycin & $116.15 \pm 0.21^{\mathrm{a}}$ & $138.23 \pm 1.72^{\mathrm{c}}$ & $22.88 \pm 1.97^{\mathrm{b}}$ \\
Infected with Synbiotic & $115.89 \pm 0.23^{\mathrm{a}}$ & $137.78 \pm 1.86^{\mathrm{c}}$ & $21.88 \pm 1.92^{\mathrm{b}}$ \\
\hline
\end{tabular}

Means with different superscripts of the same column indicate significant difference at $\mathrm{P}$ $<0.05$

Table 3 Effect of $P$. aeruginosa and treatment on blood picture of common $\operatorname{carp}(\mathrm{n}=5)$

\begin{tabular}{|c|c|c|c|c|}
\hline Groups & & $\begin{array}{l}\text { RBCs count } \\
\left(\mathrm{X} 10^{6} / \mathrm{mm} 3\right)\end{array}$ & $\begin{array}{l}\text { Hemoglobin content } \\
(\mathrm{g} / \mathrm{dl})\end{array}$ & $\begin{array}{ll}\text { Packed } & \text { cell } \\
\text { Volume }(\%) & \\
\end{array}$ \\
\hline Control group & & $2.34 \pm 0.36^{\mathrm{b}}$ & $12.81 \pm 0.28^{\mathrm{b}}$ & $30.27 \pm 0.31^{b}$ \\
\hline Flavomycin & & $4.07 \pm 0.29^{\mathrm{a}}$ & $14.78 \pm 0.27^{\mathrm{a}}$ & $33.14 \pm 0.37^{\mathrm{a}}$ \\
\hline Synbiotic & & $4.13 \pm 0.24^{\mathrm{a}}$ & $14.55 \pm 0.15^{\mathrm{a}}$ & $33.26 \pm 0.41^{\mathrm{a}}$ \\
\hline Infected & & $1.60 \pm 0.1^{\mathrm{c}}$ & $9.73 \pm 0.24^{\mathrm{c}}$ & $26.10 \pm 0.42^{\mathrm{c}}$ \\
\hline $\begin{array}{l}\text { Infected } \\
\text { Flavomycin }\end{array}$ & with & $2.21 \pm 0.36^{\mathrm{b}}$ & $11.89 \pm 0.33^{\mathrm{b}}$ & $29.56 \pm 0.32^{\mathrm{b}}$ \\
\hline Infected & with & $2.16 \pm 0.31^{\mathrm{b}}$ & $11.56 \pm 0.41^{\mathrm{b}}$ & $29.44 \pm 0.38^{\mathrm{b}}$ \\
\hline
\end{tabular}

Means with different superscripts of the same column indicate significant difference at $P$ $<0.05$

\subsection{Biochemical changes}

Regarding the protein profile (Table 4), common carp infected with $P$. aeruginosa showed significant ( $\mathrm{p} \quad 0.05$ ) reduction in serum total protein, albumin and globulin. Common carp received flavomycin or synbiotic in tested dose each alone displayed non-significant increase in total protein, albumin, globulin and A/G Ratio compared to control. Common carp infected with P. aeruginosa and received flavomycin or synbiotic showed significant increase in total protein, albumin, globulin with nonsignificant changes in $\mathrm{A} / \mathrm{G}$ ratio fish infected with $p$. aeruginosa_(Table 4).

Regarding the liver and kidney functions (Table 5), common carp infected with $P$. aeruginosa showed significant ( $\mathrm{p}$ 0.05) elevation in serum AST, ALT, urea and creatinine compared to control. Common carp infected with $P$. aeruginosa and received flavomycin or synbiotic showed significant decrease in serum AST, ALT, uric acid and creatinine compared to fish infected with $p$. aeruginosa. Common carp received flavomycin or synbiotic in tested dose each alone displayed nonsignificant change in the liver and kidney function compared to control.

\section{DISCUSSION}

Our observed result revealed that, common carp infected with $P$. aeruginosa showed clinical signs as hemorrhages on body surface, ulcerative skin, tail and fin rot, ulcers with mortality up to $32 \%$. Similar clinical signs and mortality rate were observed by EL Nagar (2010) who stated that Pseudomonas species infect various species of fish and cause pseudomonas septicemia. These clinical signs could be attributed to the pathogenic effect of $P$. aeruginosa toxins (Olgerts et al 1982). Similar signs were also observed by Amrevuawho et al. (2014) in Clarias gariepinus infected with $P$. aeruginosa. Pseudomonas aeruginosa is the important fish pathogen that induced ulcerative syndrome, bacterial hemorrhagic septicemia, tail and fin rot and ascites (Paniagua et al., 1990).
Table 4 Effect of $P$. aeruginosa infection and treatment on protein profile of common carp $(\mathrm{n}=5)$

\begin{tabular}{|c|c|c|c|c|}
\hline Groups & $\begin{array}{l}\text { T. protein } \\
(\mathrm{g} / \mathrm{dl})\end{array}$ & $\begin{array}{l}\text { Albumin } \\
(\mathrm{g} / \mathrm{dl})\end{array}$ & $\begin{array}{l}\text { Globulin } \\
(\mathrm{g} / \mathrm{dl})\end{array}$ & $\begin{array}{l}\text { A/G } \\
\text { Ratio } \\
\end{array}$ \\
\hline Control group & $\begin{array}{ll}3.89 & \pm 0.28 \\
\text { a }\end{array}$ & $1.99 \pm 0.19$ & $\begin{array}{l}1.90 \\
\pm 0.17^{\mathrm{a}}\end{array}$ & $1.05 \pm 0.08$ \\
\hline Flavomycin & $\begin{array}{l}4.38 \quad \pm 0.29 \\
\mathrm{a}\end{array}$ & $2.27 \pm 0.11$ & $2.11 \pm 0.10^{\mathrm{a}}$ & $1.07 \pm 0.06$ \\
\hline Synbiotic & $4.33 \pm 0.26^{\mathrm{a}}$ & $2.24 \pm 0.14^{\mathrm{a}}$ & $2.09 \pm 0.18^{\mathrm{a}}$ & $1.06 \pm 0.09$ \\
\hline Infected & $2.21 \pm 0.33^{\mathrm{b}}$ & $1.14 \pm 0.10^{\mathrm{c}}$ & $1.07 \pm 0.19^{\mathrm{b}}$ & $1.07 \pm 0.06$ \\
\hline $\begin{array}{l}\text { Infected } \\
\text { Flavomycin }\end{array}$ & $3.68 \pm 0.19^{\mathrm{a}}$ & $1.89 \pm 0.15^{\mathrm{b}}$ & $1.79 \pm 0.13^{\mathrm{a}}$ & $1.06 \pm 0.09$ \\
\hline Infected with Synbiotic & $3.84 \pm 0.20^{\mathrm{a}}$ & $1.97 \pm 0.19^{\mathrm{a}}$ & $1.87 \pm 0.21^{\mathrm{a}}$ & $1.06 \pm 0.07$ \\
\hline
\end{tabular}

Table 5 Effect of $P$. aeruginosa infection and treatment on liver and kidney function of common carp $(\mathrm{n}=5)$

\begin{tabular}{|c|c|c|c|c|}
\hline Groups & $\begin{array}{l}\text { AST } \\
\text { (U/L) }\end{array}$ & $\begin{array}{l}\text { ALT } \\
\text { (U/L) }\end{array}$ & $\begin{array}{l}\text { Urea } \\
(\mathrm{mg} / \mathrm{dl})\end{array}$ & $\begin{array}{l}\text { Creatinine } \\
(\mathrm{mg} / \mathrm{dl})\end{array}$ \\
\hline Control group & $28.05 \pm 0.53$ & $43.77 \pm 0.73$ & $1.78 \pm 0.09$ & $1.21 \pm 0.04$ \\
\hline Flavomycin & $30.34 \pm 0.92$ & $\underset{b}{44.13 \pm 0.61}$ & $1.82 \pm 0.16$ & $\underset{b}{1.25 \pm 0.13}$ \\
\hline Synbiotic & $30.22 \pm 0.81$ & $\begin{array}{l}44.12 \pm 0.68 \\
\mathrm{~b}\end{array}$ & $1.83 \pm 0.18$ & $\frac{1.24 \pm 0.11}{\mathrm{~b}}$ \\
\hline Infected & $33.51 \pm 0.57$ & $\begin{array}{l}46.88 \pm 0.59 \\
\mathrm{a}\end{array}$ & $1.98 \pm 0.12$ & $1.39 \pm 0.08$ \\
\hline $\begin{array}{l}\text { Infected } \quad \text { with } \\
\text { Flavomycin }\end{array}$ & $29.16 \pm 0.77$ & $\begin{array}{l}43.88 \pm 0.28 \\
b\end{array}$ & $1.80 \pm 0.12$ & $1.22 \pm 0.06$ \\
\hline Infected with Synbiotic & $29.12 \pm 0.66$ & $\underset{b}{43.89 \pm 0.27}$ & $1.79 \pm 0.12$ & $1.23 \pm 0.14$ \\
\hline
\end{tabular}

Means with different superscripts of the same column indicate significant difference at $\mathrm{P}$

In the present study it has been observed that healthy common carp fish received flavomycin and synbiotic each alone revealed significant elevation in body weight gain. Comparable results were observed by Yong, et al. (2007) in Tilapia fish. Dietary flavomycin induces increase in body weight gain of hybrid Tilapia (Zhigang, et al. 2009). Similar improvement in body weight gain was reported by Kumar, et al. (2018), who found that dietary synbiotic induced improvement in body weight gain in Tilapia and common carp. Moreover, dietary supplementation of synbiotic improved body performance in rainbow trout (Zohre, et al. 2011). The present investigation indicated that $P$. aeruginosa infection in induced significant decrease in body weight gain. Freshwater murrel infected with $P$. aeruginosa showed reduction in weight gain (Koteshwar and Benarjee, 2017). The increase in body weight gain induced by synbiotic could be attributed to the increased activities of the trypsin and chymotrypsin as recorded by Dehaghani et al. (2017).

Treatment infected carp with flavomycin or synbiotic in tested dose induced disappearance of clinical signs, reduced mortality rate to $8 \%$ and $12 \%$, respectively and reduction in re-isolation of $P$. aeruginosa. Similar observation was reported by He et al. (2010), who showed that flavomycin reduced clinical signs and reduced mortality in hybrid Tilapia. This result is further confirmed by the findings reported by Gülmez and Güven (2002), who concluded that synbiotic has a therapeutic and protective effect against many intestinal bacteria leading to prevention of many diseases. Same results were reported by Abd El hamid et al. (2009), who stated that dietary synbiotic improved protein picture in rainbow trout.

The present study revealed that, common carp experimentally infected with $P$. aeruginosa showed significant reduction in $\mathrm{RBCs}$ count, $\mathrm{Hb}$ content and PCV\%. Similar hematological changes were recorded by Koteshwar and Benarjee (2017), who concluded that Pseudomonas infection induced reduction of RBCs, $\mathrm{Hb}$ and PCV in fresh water murrel. The study also indicated that 
carp fish received flavomycin or synbiotic showed significant elevation in RBCs, $\mathrm{Hb}$ and PCV. Previous researched showed that the inclusion of probiotics with fish stimulates the hemopoiesis in fish (Marzouk et al., 2008). In addition, the PCV\% of the blood as well as increased production of erythrocytes and leukocytes were significantly increased in fish fed with a diet with the probiotic (Dahiya et al., 2012). The obtained results agreed with Chuan et al. (2010) who reported that carp fish received flavomycin showed elevation in $\mathrm{RBCs}, \mathrm{Hb}$ and PCV. Treatment of infected carp with flavomycin or synbiotic significantly increased the blood parameters compared to infected fish. It has been demonstrated that synbiotic induced elevation in RBCs, $\mathrm{Hb}$ and PCV in common carp (Ivaylo et al., 2018). Experimentally infected fish with $P$. aeruginosa showed significant reduction in serum total protein, albumin and globulin. Our obtained results agreed with those of Magdy et al. (2014), who found that $P$. aeruginosa infection induced significant reduction in serum total protein, albumin and globulin in African catfish. This could be attributed to the deleterious effect of P. aeruginosa on hepatic function. Receiving flavomycin or synbiotic each alone increased the total protein, albumin, globulin and A/G Ratio. In comparison to infected group, the addition of synbiotic or flavomycin increased the protein indices. The increased protein profile might be attributed to addition of synbiotic that improved intestinal environment which leads to increase of digestion and absorption of nutrients (Mariam et al 2010). Flavomycin improved total protein, albumin and globulin in Tilapia (Yong et al. 2007). Also, antibiotic suppress pathogenic microorganisms in intestine leading to improves absorption and assimilation of nutrient (Coles, 1986). These results were supported by Zohre et al. (2011), who stated that dietary synbiotic improved protein picture in rainbow trout.

The present study revealed that carp experimentally infected with $P$. aeruginosa had a significant elevation in serum AST, ALT, uric acid and creatinine. Our results come in agreement with those reported by Magdy et al. (2014), who demonstrated that $P$. aeruginosa infection in African Catfish show significant increase in AST, ALT, uric acid and creatinine. The increased level of hepatic and liver function could be attributed to the increased lipid peroxidation that caused oxidative damage to the hepatic and kidney cells (Magdy et al., 2014). Fish received flavomycin or synbiotic each alone revealed produced nonsignificant elevations of serum AST, ALT, urea and creatinine. Liu et al. (2009) found that flavomycin increased AST, ALT, urea and creatinine in healthy Tilapia and Cyprinus Carpios. However, Ghasempour (2015) concluded that dietary synbiotic has no effect on ALT and AST, urea and creatinine of common carp. Also, Khalesi et al. (2018) found that synbiotic does not affect serum ALT, $\mathrm{AST}_{2}$ uric acid and creatinine levels. On the other hand, Hassanein et al. (2017) noticed that treated diets with probiotic S. cerevisiae, or L. acidophilus significantly decreased ALT and AST values compared to control group. Soltan and El-Laithy (2008) found that, ALT and AST levels significantly decreased when Nile tilapia fed diets supplemented with probiotics compared to control group.

\section{CONCULSION}

It could be concluded that flavomycin or synbiotic helps in treatment $P$. aeruginosa infection and induced improvement in hematobiochemical parameters. Therefore, it is recommended to add flavomycin or synbiotic in common carp diet as growth promoters.

\section{REFERENCES}

1. Abd El hamid, A.; Mehrim, M. and Abd El-Wahab, A. (2009). Evaluation of a New Egyptian Probiotic by African Catfish. J Env Sci and Tech., 2 (3): 133-145,

2. Amrevuawho, M.; Akinyemi, A. and Takeet, O. (2014). Pathological study of clarias gariepinus infected with p aeruginosa. Braz. J. Aquat. Sci. Tech. 18(2):65-70

3. Cheesborough M (1984). Medical Laboratory manual for tropical countries. Vol. II. Microbiol., P. 248-264.

4. Chuan, Z.; Peng, L.; Guang, X. and Jun1, Y. (2010). Effects of flavomycin on some hematological and biochemical changes in crucian carp. Indian Vet. J. 87: 341-346.

5. Coles, E. (1986). Veterinary Clinical Pathology. $4^{\text {th }}$ Ed. W.B. Saunders Comp, Philadelphia, London, Toronto, Mexico City, Rio de Janeiro, Sydney, Hong Kong.

6. Dahiya T, Sihag RC and Gahlawat SK (2012). Effect of probiotics on the haematological parameters of Indian magur (Clarius batrachus L.). Journal of Fisheries and Aquatic Science 7(4): 279-290.

7. Dehaghani, P. G., Baboli, M. J. Moghadam, A. T. ZiaeiNejad, S. and Pourfarhadi, M. (2015). Effect of synbiotic dietary supplementation on survival, growth performance, and digestive enzyme activities of Common carp (Cyprinus carpio) fingerlings. Czech Journal of Animal Science, 60(5): 224-232.

8. Doumas, B.; Carter, R.; Peers, T. and Schaffer, R. (1981). Method for determination of total protein in serum. Clin Chem. 27.1650-1642 .

9. Drupt, F. (1974). Calorimetric method for determination of albumin. Phar. Bio, 9: 77

10. Edwards, J.; Mc Ewan, N. and Wallace, R. (2005). Influence of flavomycin on ruminal fermentation and microbial populations in sheep. Microbiology, 151:1725 .

11. Eissa, N..; Abou El-Ghiet, E.; Shaheen, A. and Abbass, A. (2010). Characterization of Pseudomonas Species Isolated from Tilapia "Oreochromis niloticus" in Qaroun and Wadi-El-Rayan La kes, Egypt. Glob. Vet., 5: 116-121

12. El-Ghamry, A.; El-Mallah, G. and El-Yamny, A. (2002). Effect of incorporating yeast culture Nigella sativa seeds and fresh garlic in broiler diets on their performance. Egypt. Poult. Sci. 22(11): 445-459.

13. El-Nagar, R. (2010). Bacteriological studies on pseudomonas microorganisms in cultured. M. Sc. Thesis, Fac. Vet. Med., Zag. University

14. Fairchild, A.; Grimes, J. and Sefton, A. (2001). Effects of Bio-Mos, and Flavomycin on poultry susceptibility to oral E coli challenge. Poult Sci., May; 80 (5): 56271.

15. Fawcet, J. and Scott, J.(1960): Determination of urea. J. Clin. Path.(13) 156.

16. Ghasemi, H.A., Kasani N., Taherpour K. (2014). Effects of black cumin seed (Nigella sativa L.), a probiotic, a prebiotic and a synbiotic on growth performance, immune response and blood characteristics of male broiler. Livestock Sci 164,2834

17. Ghasempour, D.; Mehran, J.; Ahmad, t. and Saeed, Z. (2015). Effect of synbiotic on survival, growth performance, and digestive enzyme activities of common carp (Cyprinus carpio) fingerlings. Czech Journal of Animal Science 60(5):224-232

18. Gülmez M. and Güven A. (2002). Probiyotik, Prebiyotik ve Sinbiyotikler. Kafkas Univ. Vet. Fak. Derg. 8(1) 83-89. 
19. Hassanien, A., El-Moghazy, G., Iraqi, M., Soltan, M., Elsayad, G. (2017). 'Physiological and haematological responses of the Nile tilapia (Oreochromis niloticus) fed on diets supplemented with probiotics', Egyptian Journal of Aquatic Biology and Fisheries, 21(1), 25-36.

20. Hassanpour, H., Zamani Moghaddam, A.K., Khosravi, M.M. (2013). oral immune response in broiler chickens. Livestock Science 153, 116-122.

21. He S, Zhou Z, Liu Y, Cao Y, Meng K, Shi P, Yao B, Ring $\varnothing$ E.( 2010). Effects of the antibiotic growth promoters flavomycin and florfenicol on the autochthonous intestinal microbiota of hybrid tilapia. Arch 192 (12):985-994.

22. Husdan, H. and Raporpot, A. (1968). Estimation of creatinine. Clin. Chem (4)22.

23. Lvaylo, S.; Katya, V.; Rayna, A. And Yordan, S (2018). effect of synbiotic on growth, physiological and immunological parameters in common carp fingerlings and on yield and physiological parameters in lettuce cultivated in mesocosms aquaponic system. Bulgarian J. of Agri cultural Sci, 24 (1), 140-149.

24. Jain, N.C. (1986). Schalm's Veterinary Hematology 4th Ed., Lee and Febiger, Philadelphia, U.S.A. Pp.5596

25. Khalesi S.; Johnson D.; Saluja S. and Irwin C. (2018). Effect of probiotics and synbiotic consumption on serum concentrations of liver function test enzymes: a systematic review and meta-analysis. Eur J Nutr., 57(6): 2037-2053.

26. Khalil, R.; Atallah, S; Soliman, M.; and Mahfouz, N. (2001). Economic losses due to fish diseases at the farm level. Aquaculture Europe, Trondheim, Norway, 3-7.

27. Koteshwar, R. and Benarjee, G. (2017). body performance and Haematological changes in South Indian fresh water murrel, Channa punctatus have Pseudomonas aeruginosa infection. J Parasit Dis. 2017 Jun; 41(2): 329-335.

28. Kumar, P.; Jain, K. and Sardar, P. (2018). Effects of synbiotic on immunity, antioxidant activity and disease resistance of Cirrhinus mrigala juveniles. Fish Shellfish Immunol. 80:124-132.

29. Li, L. Bai, Q. Xu, H. and Zhang, T. (2008). Effects of dietary flavomycin on growth performance and nonspecific immunity function in rainbow trout Oncorhynchus mykiss, J. Dalian Fish. Univ. 23. Pp. 179-184.

30. Liu, A.; Leng, X. and Li, X. (2009). Effect of flavomycin and mannan oligosaccharides on growth performance and some biochemical parameters in tilapia (Oreochromis niloticus $\times$ O.aureus). J. Dalian Fish. Univ. 24, 15-23.

31. MacFadden, JF (2000). Biochemical tests for Identification of Medical Bacteria 3rd Ed. The Williams \& Wilkins Co., USA. Pp. 689-691.

32. Magdy, M.; El-Hady, M.; Ahmed, H. and Kenwy, M. (2014). A contribution on P. aeruginosa infection in African Catfish. Res J Pharm Biol Chem Sci., 5: 575588.

33. Mariam G., Eman M., and Stino, R. (2010). Effect of synbiotic on reduction of ochratoxicosis, enhancement of immunity in quail hen. Amer Sci J., 6(11) 35-42
34. Marzouk MS, Moustafa MM, and Mohamed NM (2008). Evaluation of immunomodulatory effects of some probiotics on cultured Oreochromis niloticus. 8th International Symposium on Tilapia in Aquaculture Pp. 1043-1058

35. Olgerts R. Pavlovskis and Bengt W. (1982). Pseudomonas aeruginosa toxins. Medical Microbiology, 1: 97-128.

36. Paniagua, C.; Rivero, O. and Naharro, G. (1990). Pathogenicity Factors and Virulence for Rainbow Trout (Salmo gairdneri) of Motile Aeromonas spp. Isolated from a River. J Clin Microbiol., 28(2):350-355.

37. Parker, D.S. and D.G. Armstrong, (1987). Antibiotic feed additives and livestock production. Proc. Nutr. Soc., 46: 415-421.

38. Petrie, A. and Watson, P. (1999) Statistics for Veterinary and Animal Science $1^{\text {st }}$ Ed. 90-99, The Blackwell Science LTd, United Kingdom.

39. Reilly, A. and Kaferstein, F. (1997). Food safety hazards and the application of the principles of the hazard analysis and critical control point (HACCP) for their control in aquaculture production. Aquac. Res., $28,735-52$.

40. Reitman, S. and Frankle, S. (1957). A colorimetric determination of GOT and GPT activity. Am. J. Clinic.Path.28:56.

41. Roberts, R. (2001). "Fish pathology" $3^{\text {rd }}$ Ed, Bailliere tindall, London England.

42. Soltan, M. A. and El-Laithy, S. M. M. (2008). Effect of probiotics and some spices as feed additives on the performance and behavior of Nile tilapia, Oreochromis niloticus. Egypt. J. Aqua. Biol. \& Fish., 12(2):63-80.

43. Somsiri, T. and Soontornvit, S. (2002). Bacterial diseases of cultured tiger frog (Rana tigerina). In C. Lavilla-Pitogo and E. Cruz-Lacierda (eds.), Diseases in Asian Aquaculture IV, Fish Health Section, Asian Fisheries Society, Manila

44. Van Heijenoort, J. (2001). Formation of the glycan chains in the synthesis of bacteria peptidoglycan. Glycobiology, 11: 25R-36R

45. Wakabayashi $\mathrm{H}$ and Egusa S (1972). Characteristics of a Pseudomonas sp. from an epizootic of pond-cultured eels (Anguilla japonica). Bulletin of the Japanese Society of Scientific Fisheries 38 (6): 577-587.

46. Yong, X., Caihong, H., \& Li, X. (2007). Effects of flavomycin on growth performance, microbial ecology and immunity of Nile tilapia. Journal of Northwest SciTech University of Agriculture and Forestry. 35 (9). 29-34.

47. Zhigang, Z.; Yuchun, L.; Suxu, H. and Einar R. (2009 ).Effects of dietary potassium diformate and flavomycin on growth performance, feed conversion and intestinal bacterial community of hybrid tilapia. Aquaculture, 291(1): 89-94

48. Zohre, M.; Farid, F. and Ali, J. (2011).Effects of dietary supplementation of synbiotic on growth performance, serum biochemical parameters and carcass composition in rainbow trout fingerlings $\mathrm{J}$ Anim Phys. Anim Nutr 96(3):474-81. 